\title{
STUDiEs ON AUSTRALIAN MOLLUSCA. Part IX.
}

\author{
By C. Hedley, F.L.S.
}

(Plates xxxi.-xxxiii.)

(Continued from Vol. xxix, p.211).

Haliotis cyclobates Péron.

A prolific collecting ground was traversed by Péron on Kangaroo Island, South Australia. At the mouth of the little "Port Daché," the Pelican Lagoon of our Admiralty chart, two handsome species of Haliotis especially attracted his attention. One, whose perforations project so as to form open truncated cones, he named H. conicopora. This answers to the $H$. tubifera of Lamarck, which has been referred to H. ncevosa Martyn, but which may perhaps be $H$. granti Pritchard and Gatliff.

A second Haliotis, which Péron named H. cyclobates, "because of its very deep and almost round aperture"* is evidently the $H$. excavata of Lamarck, $\dagger$ distinguished as an " espèce singulièrement remarquable par sa profonde excavation et sa forme presque ronde," brought by Péron from New Holland.

Remembering that Lamarck, who had no scruples about discarding names, had the notes and specimens of Péron at his disposal, the coincidence of description, locality, and collector amount to proof that these names are synonymous. H. cyclobates Péron, must replace $H$. excavata Lamarck, over which it enjoys six years' priority.

While on the subject of Australian Haliotis, I may add that $H$. hargravesi Cox, is quite distinct from $H$. roei Gray, with which Pilsbry $\ddagger$ has united it. H. hargravesi grows no larger

* Péron, Voy. Terr. Aust. ii. 1816, p. 80.

+ Anim. s. vert. vi. (2), 1822, p.215.

$\ddagger$ Man. Conch. xii. 1890, p.118. 
than the original figure; it is peculiar to the coast of New South Wales, whereas $H$. roe $i$ is exclusively a West Australian species.

It further seems to me that $H$. rubicundus Montfort, should replace the later $H$. tricostalis Lamarck. Montfort's name, which Pilsbry marked as very doubtful, was recognised and accepted by Dr. J. E. Gray, ${ }^{*}$ who had unusual facilities for ascertaining the facts of the case.

Emarginula incisura A. Adams.

A. Adams, Proc, Zool. Soc. 1851, p.84.

No locality was known for this species when it was announced by A. H. Cooke $\uparrow$ from the Gulf of Suez. It was afterwards reported by E. A. Smith $\ddagger$ from the Maldives.

All these records were based on single specimens. But Mr. G. Gross has shown me numerous examples which he gathered in Moreton Bay. It has been obtained also at Caloundra, Queensland, by Mr. H. L. Kesteven. Since, at the time the species was described, the London market was flooded with the Moreton Bay shells of F. Strange, it is probable that the type was a Queensland shell.

Emarginula dilecta A. Adams.

(Plate xxxiii., figs.37-38).

This species was originally described from King George's Sound, W.A., and was afterwards figured by Sowerby.\| It was added to our fauna by Angas, 9 who again announced it $\operatorname{as}_{\infty}{ }^{\infty}$ fresh discovery, ${ }^{* *}$ and remarked later $\dagger \dagger$ that he had in the first instance mistaken $E$. candida A. Ad., for this species. Tenison

* Gray, King's Survey Trop. Austr. Append. ii. 1827, p.495.

† Ann. Mag. Nat. Hist. (5), xvi., 1885, p.271.

‡ Fauna Geogr. Maldive \& Laccadive Arch. ii. 1903, p.618.

§ Proc. Zool. Soc. 1851 (1852), p.85.

\| Thes. Conch. iii. 1863, pl.245, f.5.

I Proc. Zool. Soc. 1867, p.219.

** Proc. Zool. Soc. 1871, p. 97.

t† Proc. Zool. Soc. 1877, p.189. 
Woods commented* on this confusion. Henn and Brazier $\uparrow$ recognised $E$. dilecta from Watson's Bay.

The distinction between $E$. dilecta and $E$. candida is not made clear in literature, and I have found the species difficult to identify. Dr. J. C. Verco, who has examined the types of each in the British Museum, kindly points out to me that, from the apex to the notch, E. dilecta has a furrow but E. candida a ridge. To facilitate recognition, I add a drawing of an example of $E$. dilecta, $13 \mathrm{~mm}$. long, from Maroubra beach. According to my experience $E$. dilecta is a rare shell here, and only occurs on the ocean beaches.

\section{Diala translucida, n.sp.}

(Plate xxxiii., fig.35.)

Shell of variable form, ovate conic, sometimes broader in proportion to height than the figure, smooth and glossy, very thin, usually transparent enough for the axial pillar to be seen through the whorls. Whorls nine, regularly tapering, first disproportionately minute, others rounded, last sometimes subcarinate, a row of opaque spots often occurs on the periphery. Aperture oblong, sometimes effuse anteriorly. Columella straight, a little thickened. Length $5 \cdot 6$, breadth $2 \cdot 6 \mathrm{~mm}$.

Hab.-Balmoral Beach, Sydney (the late Mrs. C. T. Starkey).

T y p e.-To be presented to the Australian Museum.

This shell is, like its congeners, very variable. The transparent shell distinguishes it from other Australian Diala, and the straight columella will serve to separate it from such translucent shells as Eulima or Stylifer, to which it has a deceitful resemblance. Mr. J. H. Gatliff, who detected this species in Victoria, compared it to the Queensland A. goniochila Ad. The northern shell differs by its subulate spire and much smaller size.

* Proc. Roy. Soc. Tas. 1876, p. 103.

† These Proceedings (2), ix. 1894, p.178. 
Diala monile A. Adams.

(Plate xxxiii., fig.36.)

Alaba monile A. Ad., Ann. Mag. Nat. Hist. (3), x. 1862, p. 296.

This shell has never been illustrated. I therefore present a drawing of a Tasmanian shell $5 \mathrm{~mm}$. in length, such as is accepted by local collectors for the above species.

It ranges as far north as Broken Bay, N.S.W.*

Alaba (Styliferina) sulcata Watson.

This species was represented in the "Challenger" collection by a single shell dredged in six fathoms off Cape York, Queensland. $\dagger$ Concerning it Dr. Watson remarked, "I do not feel at all certain that this is a Styliferina; it may be only a young shell of some other genus."

These doubts were well founded, for a series I dredged last year off the Capricorn Islands, Queensland, prove Watson's species to be the apex of Strombus campbelli Gray. It is noteworthy that the same haul which gave Watson his Alaba sulcata included Strombus campbelli in the adult stage.

While on the subject of East Australian Alaba I may point out that three species were omitted from an enumeration of the genus by Mr. E. A. Smith. $\ddagger$ Perhaps as a consequence they have since been renamed.

Alaba flammea Pease, $\S$ which ranges down the whole length of the Great Barrier Reef, seems to me a prior name of Diala albugo Watson.||

Alaba semistriata Philippi, 9 whose Australian distribution is similar to that of the preceding species, appears to me to differ

* Hedley, Mem. Austr, Mus. iv. 1903, p.352.

† Watson, Chall. Rep. Zool. xv. 1886, p.570, Pl. xlii. f.7.

$\ddagger$ Proc. Zool. Soc. 1875, p.538.

§ Am. Journ. Conch. iii. 1867, p. 297, Pl. xxiv. f.33.

|| Chall. Rep. Zool. xv. 1886, p.568, Pl. xlii. f.3.

- Zeitsch. Malak, vi. 1849, p.34; Savigny, Descr. Egypte, Pl. iii., f.27, 28. 
only in colour, in which character it is variable, from Barleeia imbricata Watson.*

Alaba martensi Issel, $\uparrow$ associated geographically with the foregoing, is apparently inseparable from Diala hardyi Melvill \& Standen. +

Alaba fulva Watson, its variety pyrrhacme Melvill \& Standen, and Alaba striata Watson, are to be transferred to Obtortio. The latter species has occurred at Thursday Island.

\section{Eulimella anabathron, n.sp.}

(Plate xxxiii., figs.39, 40.).

Shell tall, slender, opaque, rather fragile. Whorls ten, exclusive of a prostrate heterostrophe apex of two whorls, deeply constricted at the suture and produced at the periphery in to a ridge or crest. Colour white. Sculpture : no spirals; coarse irregular riblets proceed from the lower suture in a backward convex curve to the peripheral crest, thence in a concave curve to the upper suture. Aperture ovate, columellar margin a little reflected, appressed to the preceding whorl. Length 4.8 ; breadth $1.2 \mathrm{~mm}$.

Hab. - Balmoral Beach, Middle Harbour (the late Mrs. C. T. Starkey).

T y p e.-To be presented to the Australian Museum.

\section{Odostomia opaca, n.sp.}

(Plate xxxiii., fig.41.)

Sheli cylindro-conic, solid, opaque. Whorls five, exclusive of the protoconch. Colour buff or pale purple, zoned with three narrow spiral lines, one running below the suture on the last four whorls, another on the periphery of the last two whorls, and the other on the base of the final whorl. Sculpture: regularly spaced smooth round prominent radial ribs which project at the suture,

* Chall. Rep. Zool. xv. 1886, p.584, Pl. xliii. f.2.

† Malacologia Mar Rosso, 1869, p.206; Savigny, Descr. Egypte, Pl. iii., f.26.

‡ Journ. of Conch. viii. 1895, p.118, Pl. ii., f.10.

$\S$ Hedley, Mem. Austr. Mus. iii. 1899, p.412. 
bend a little on crossing the whorl, and taper on the base. The last whorl has about twenty; they do not continue from whorl to whorl, but are interrupted at the suture. There is no trace of spiral sculpture. Aperture small, perpendicular, rounded beneath, angled above, peristome slightly thickened, columeliar fold slight, oblique. Length 2.95 , breadth $1.1 \mathrm{~mm}$.

$H a b$. _Chinaman's Beach, near Sydney; two specimens in shell sand (Miss L. Parkes).

T y p e.-Miss Parkes has kindly presented her type-specimen to the Australian Museum.

A form, apparently a variety of this, has been collected at Caloundra, Queensland, by H. L. Kesteven. It is smaller than the Sydney specimens, and white with three orange spiral threads.

The Queensland O. pupa Watson, and O. kymatodes Watson,* seem allied, but according to the description the former has feebler ribs, and in the latter the broadened summits of the ribs coalesce and crown the whorls with a continuous ridge. Neither species has the dark spiral lines.

Herviera isidella Melvill \& Standen, $\uparrow$ from New Caledonia, is much like this, but differs in outline, has narrower, straighter ribs and no colour bands. The genus Herviera appears superfluous; in forming it the authors probably overlooked Odostomella Bucq. Dautz \& Dollf. $\ddagger$

\section{Leiostraca inUsta, n.sp.}

(Plate xxxiii., fig.43.)

Shell small, thin, almost translucent, blunt-topped, smooth. Whorls six and a half, gradually increasing. Colour white, baser aperture, and sometimes a varix, cinnamon-brown. No sculpture except a few weak irregular varices. Sutures ragged. Aperture oval, peristome slightly thickened and reflected. Length 2.75 , breadth $0.85 \mathrm{~mm}$.

Hab.-Manly Beach (Miss L. Parkes).

Ty pe.-To be presented to the Australian Museum.

* Chall. Rep. Zool. xv. 1886, p.486.

† Journ. of Conch. ix 1899, p. 186, fig.

$\ddagger$ Moll. Mar. Rosillon, i. 1853, p.167. 


\section{Rissoa emblematica, n.sp.}

(Plate xxxii., fig.24.)

A "Rissoa" of the group of $R$. cheilostoma, small, short, stout, solid and glossy. Whorls four, parted by impressed sutures, the first three forming less than half the shell, the last becoming ultimately detached. Colour : amber, darkening to brown on the base, peristome white. Sculpture: the minute umbilicus is margined by a heavy spiral ridge which runs up into the anterior corner of the peristome. To this succeeds a groove and a second spiral ridge, upon which are planted the bases of a dozen thick, oblique radiating ribs. Ascending to the shoulder, these ribs there project as heavy buttresses, giving to the whole shell a peculiar angular expression. From the shoulder these ribs diminish rapidly to the suture, which they undulate. The shoulder buttresses are linked each to the next by a spiral ridge. On the last whorl behind the aperture, the radial ribs vanish, but the shoulder links continue to the peristome as a prominent undulating cord. A secondary sculpture of minute spiral undulating scratches covers the entire surface without reference to the features of the major sculpture. The basal cord, radiating buttress ribs and shoulder links are repeated on the third whorl. The second whorl is broadly tabulate, but unsculptured. The apex is tilted, so appearing papillate. Aperture in the plane of the axis, oblong, surrounded by a heavy, widely projecting, complete peristome, doubled by a groove on its face. Length 4 , breadth $2 \mathrm{~mm}$.

Hab.-Manly Beach, Chinaman's Beach (Miss L. Parkes), Middle Head and Wreck Bay, N.S.W. (C. Hedley).

Ty pe.-To be presented to the Australian Museum.

From its nearest allies the comparative simplicity of sculpture, the predominance of radii over spirals, distinguish it.

Rissoa pulvillus, n.sp.

(Plate xxxii., fig.25.)

Shell small, oblong-ovate, imperforate, thin and glossy. Whorls four and one-half, inflated. Colour: upper part uniform ochreous- 
brown, the last two whorls dull white, each crossed by two narrow spiral brown bands, base and part of peristome dark chocolate. Sculpture : the smooth surface scarcely roughened by microscopic growth-lines. Aperture subcircular, peristome complete, a little expanded. Length $2 \cdot 44$, breadth $1.08 \mathrm{~mm}$.

Hab.-Manly Beach, in shell sand (Miss L. Parkes).

T y p e.-To be presented to the Australian Museum.

\section{LæVILITORINa MaRiÆ Ten. Woods.}

This species was originally described by Tenison Woods as Rissoa (Cingula) marice, * from King's Island. It was figured by Tryon. $\uparrow \quad$ By Pritchard \& Gatliff it was reported from Victoria; and by Tate \& May from S. Australia.§ A specimen I collected at the entrance of Sussex Inlet enables me to add it to the fauna of this State.

It is here proposed to transfer the species from Rissoa to Pfeffer's genus Lavilitorina, || with the type of which, L. caliginosa Gould, I have compared it, and to which it closely corresponds. Lavilitorina is represented by three species in New Zealand, but is now first announced as Australian.

Assiminea tasmanica Ten. Woods

(Plate xxxii., figs. 27, 28, 29.)

Two names were bestowed on Tasmanian examples of this species by Tenison Woods; firstly Assiminea tasmanica, $\mathbf{T}$ secondly Rissoa siennce. ** Subsequently the second name was withdrawn by its author. $\dagger \dagger$ A figure of the shell was given by W, F. Petterd. $\ddagger \ddagger$

* Proc. Roy. Soc. Tasm. 1875 (1876), p.147.

+ Man. Conch. ix. Pl.71, f.9.

$\ddagger$ Proc. Roy. Soc. Vict. xiv. 1902, p.108.

§ These Proceedings, xxvi. 1901, p.459.

|| Jahrb. Anst. Hamburg, iii. 1886, p.81.

T Proc. Roy. Soc. Tas. 1875 (1876), p.79.

** Proc. Roy. Soc. Tas. 1876 (1877), p.153.

+† Proc. Roy. Soc. Tas. 1879 (1880), p. 70.

芰 Proc. Roy. Soc. Tas. 1888 (1889), pl. ii., f.2. 
Formerly Prof. Tate reduced it* to a synonym of Paludina granum Menke; but ultimately $\dagger$ restored it to its former position.

Incidentally it may be here remarked that Paludina granum is a West Australian species whose description does not agree with A. tasmanica, and whose figure $\ddagger$ was not then known to Prof. Tate. Nevill had referred P.granum to the genus Larina.§ It is not to be confused with Assiminea granum Morelet, which by its author was finally regarded $\|$ as a synonym of Hydrocena hidalgoi Gassies.

The shell was noticed by Mr. J. H. Gatliff $₫$ in Western Port, Victoria. By Mr. T. Whitelegge it was added** to the fauna of this State. It is abundant under sticks and stones and on weed near high water mark in mangrove swamps. The individual figured, $3.25 \mathrm{~mm}$. long, I took in the Lane Cove near Sydney. The species ranges north at least as far as the Richmond River. In Queensland it is replaced by a species known by the MS. name of $A$. affinis Mousson. ††

Mr. F. E. Grant, who kindly drew for me the accompanying figure of the radula, points out how closely it resembles the radulæ of other species of Assiminea illustrated by Troschel. $\ddagger \ddagger$

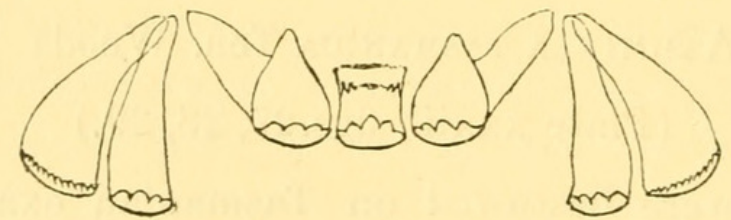

The operculum, of which I show both aspects (Pl.xxxii., f.28, 29), has not been previously figured.

* These Proceedings, vi. 1881, p.389.

+ These Proceedings, xxvi. 1901, p.305.

‡ Philippi, Abbild. Beschr. Conch. v. 1844, pl. iii., f.16.

$\S$ Cat. Moll. Indian Mus. 1877, p.21.

\| Journ. d. Conch. xxxi. 1883, p.208.

ศा Vict. Naturalist, xxii. 1905, p.15.

** Journ. Proc. Roy. Soc. N. S. Wales, 1889, p.321.

t+ Cat. Godeffroy Museum. v. 1874, p.103. Nevill, Handlist Moll. Indian Museum, ii. 1884, p.70.

怙 Gebiss d. Schnecken, i. 1856, pl. vii., f.13, 14. 


\section{Macclotriton Bracteatus Hinds.}

In a recent revision of this species it is suggested by Pilsbry and Vanatta* that Cantharus Waterhousice Braziert is a related form. On again examining Brazier's species, I am unable to separate it from that of Hinds. An unrecorded synonym appears to be Columbella epidelia Duclos. $\ddagger$

The species has not otherwise been recorded from Australia. In my experience though widespread it is nowhere common. I found it at the Palm Islands and the Capricorn Group, Queensland, and have seen specimens from Lord Howe Island.

\section{Cerithiopsis Cessicius, nom. mut.}

This species was introduced by Tenison Woods under the name of Bittium minimum. $\$$ By Messrs. Tate and May it was transferred to Cerithiopsis.| - Unfortunately this trivial name was already employed in Cerithiopsis. Cerithium minimum described by Brusina in 1864, was by Monterosato placed 9 as a variety of Cerithiopsis tubercularis. The latest notice, ${ }^{*}$. however, ranks the Mediterranean form as a full species under the title of Cerithiopsis minima Brusina. For the Australian shell a new name is therefore required, and is here proposed.

\section{Pyrazus herculeus Martyn.}

Because this was one of the half-dozen shells which the companions of Captain Cook are known $\uparrow \dagger$ to have gathered at Botany Bay in April, 1770, it will always have a sentimental interest for Australian collectors.

On the return of the "Endeavour" to England, G. Humphries, a celebrated naturalist of that period, acquired some of the shells

* Proc. Acad. Nat. Sci. Philad. lvi. 1904, p.593, † These Proceedings, xxiv. 1899, p.434, f. 7 .

† Duclos in Chenu, Illustr. Conch. Columbella, 1846-1858, pl. xxv., f.17-18. § Proc. Roy. Soc. Tas. 1877 (1879), p.123,

|l These Proceedings, xxvi. 1901, p.385.

T Journ. de Conch. xxii. 1874, p.272.

** Watson, Journ. Linn. Soc. Zool. xxvi. 1897, p.280. †† Von Martens, Malak. Blätt. xix. 1872, p.29. 
collected during the Expedition. Through him the specimens were dispersed to various European conchologists. Spengler seems to have been the first to publish an account of this species. ${ }^{*} \mathrm{He}$ was shortly followed by Zorn $\dagger$ Neither of these authors employed Linnean nomenclature, and their writings have therefore only an historical interest for systematists.

From material provided by Humphries, our shell was next superbly pictured by Thomas Martyn $\ddagger$ under the title of Clava herculea, a name long neglected, but whose right to use is indisputable. Martyn erroneously credited his shell to the Friendly Islands. In the same year, the Catalogue of the Portland Museum, drawn up by Dr. Solander, advertised the shell as " the black Hercules Club from New South Wales."

Under a polynomial name, Chemnitz§ refigured and described the species, giving an account of the literature, which was already considerable. Then Bruguière,\| who had actually never seen the shell, imposed upon it the name of Cerithium ebeninum, and compiled a description from the work of his predecessors.

Montfort increased the synonomy by renaming it Pyrazus baudini; T his specimen was brought from Australia by Baudin's Expedition.

The fourth and last name was bestowed by Perry, who called a shell from " the East Indies" Cerithium ferruginosum. **

After this date the shell became well known to European collectors under Bruguière's name, which, supported by Lamarck $\uparrow \dagger$ and Gray, $\ddagger \ddagger$ circulated generally. An imperfect bibliography has been lately issued by L. Vignal.\$§

* Naturforscher, ix. 1776, p.145 pl. v., f.3.

† Abhandl. danziger naturf. Gesellsch. i. 1778, p.173.

† Universal Conchologist, i. 1784, p.13.

§ Conch. Cab. x. 1788, p.257, pl. clxii., f.1548, 1549.

|| Ency. Méth. Vers (2), 1792, p.490.

- Conch. Syst. ii. 1810, p.459, pl. exv.

** Conchology, 1811, pl. xxxvi., f.1

†十 Anim. s. vert. vii. 1822, p.67.

拉 Append. King's Survey, ii. 1827, p.483.

$\S \S$ Journ. de Conch. liii. 1905, p.33. 
Having stated the case for the specific name, that of the genus now requires consideration. The first used was Clava, but Dall* has shown that this name should be restricted to the group usually called Vertagus. Bruguière placed it in Cerithium, the modern limits of which are too narrow to include his C.ebeninum. Reeve aud subsequent authors include our species in Potamides, a genus framed for a French Tertiary fossil. The original references to this genus are not within my reach, but I find that according to Agassiz, $\uparrow$ the publication of Potamides by Alex. Brongniart $\ddagger$ dates only from 1822 . But P. herculeus is the type of Pyrazus instituted in 1810, hence even if, as most authors consider, Potamides and Pyrazus refer to one genus, then Pyrazus must take precedence.

The animal was described and figured by Quoy and Gaimard.§ Tenison Woods gave some account of the radula and eye.\| The nervous system and other anatomical features were examined by E. L. Bouvier. .

As a subfossil it was recorded from the neighbourhood of Brisbane by Jack and Etheridge;** from Maitland, N.S.W., by Darid and Etheridge, $\uparrow \dagger$ and from Shea's Creek by Etheridge, David and Grimshaw. $\ddagger \ddagger$

No doubt the species was largely used as food by the coast natives. The aborigines of Moreton Bay, Queensland, called the species Toondah.\$ It was found by Anderson|\|I in kitchen middens on the Wagonga River, N. S. Wales. Waite notes $\Phi$ I that

* Trans. Wagner Inst. Sci. iii. 1892, p.290.

+ Nomenclator Zoologicus, 1842, Mollusca, p.74.

$\ddagger$ Description géologique des couches des environs de Paris.

$\S$ Voy. Astrolabe, Zool. iii. 1834, p.123, pl. lv., f.1-3.

|| Journ. Roy. Soc. N. S. Wales, xxii. 1898 (1889), p.150, pl. iv., f.4; pl.v. f. 6 ; pl. vi., f.7.

ๆ Ann. Sci. Nat. (7), Zool. iii. 1887, p.142, pl. vii., f.28, copied Perrier Traité Zool. iv. 1897, p.2036, f.1473.

** Geol. and Paleont. Queensland, 1892, p.642, pl. xxxvi., f.14-16.

t十 Rec. Geol. Survey N. S. Wales, ii. 1890, p.48.

持Journ. Roy. Soc. N. S. Wales, xxx. 1896 (1897), p.169.

$\S \S \mathrm{S}$. Kent, Great Barrier Reef, 1893, p.253.

III Rec. Geol. Survey N. S. Wales, ii. 1890, p.56.

ฯ ๆ These Proceedings (2), ix. 1895, p.562. 
they are sold for food under the name of "whelks" in the Sydney markets.

Eighteenth century writers record the species in error from New Zealand and the Friendly Islands. On the strength of "A single dead specimen," it has been ascribed to Lord Howe Island.* Round Sydney, as Angas and Whitelegge remark, $\uparrow$ it is very abundant. I have traced it north to the edge of the tropics, where in Port Curtis its range overlaps that of its relations, Pyrazus semitrisulcatus Bolten, P. fluviatilis Potiez \& Michaud, and Telescopium telescopium Linn. Here the shell is reduced in size as if struggling against adverse conditions. In the south I have taken it in Twofold Bay. Pritchard and Gatliff note it from Malacoota Inlet, Victoria; $\ddagger$ and Tate \& May from Frederick Henry Bay, Tasmania.§ It has been vaguely reported from South Australia by Adeock. $\|$

The species is strictly estuarine, and is commonly associated with Arca lischkei. It crawls among the roots of the Avicennia mangrove and on Zostera flats between tide marks. A young oyster is often mounted on the back of the whelk shell. 9

Mr. F. E. Grant has kindly prepared for me the accompanying view of the radula. He notes that "a shell $86 \mathrm{~mm}$. in length

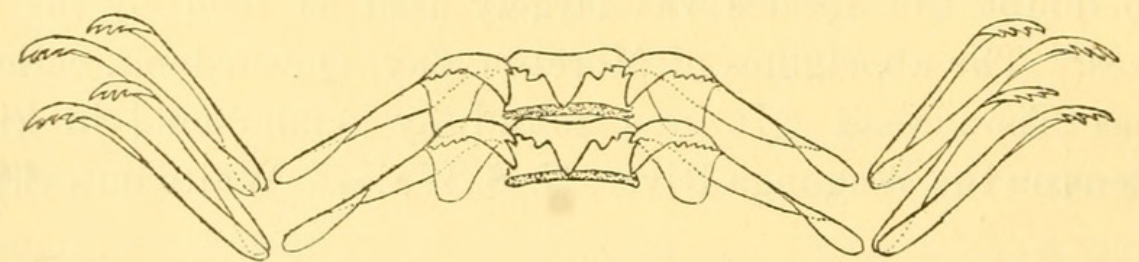

produced a radula $6 \mathrm{~mm}$. long of $94+$ ? rows, and $0.95 \mathrm{~mm}$. broad when the uncini are folded over the laterals. Radula of normal Tænioglossa form 2, 1, 1, 1,2. Rachidian with large median cusp and two small laterals on either side. Lateral teeth with

* Etheridge, Mem. Austr. Mus. ii. 1889, p. 23.

† Angas, Proc. Zool. Soc. 1867, p.208; Whitelegge, Journ. Roy. Soc. N. S. Wales, xxiii. 1889 , p.266.

$\ddagger$ Proc. Roy. Soc. Vict. n.s. xiii. 1900, p.156.

$\S$ These Proceedings, xxvi. 1901, p,387.

|| Hand List Aquatic Mollusca South Australia, 1893, p.7.

- T Saville Kent, Great Barrier Reef, 1893, pl. xiv. f.9. 
first cusp small followed by a large cusp, which is again succeeded by about four or five small cusps in a diminishing series. Below these there is a prominent truncated lobe reaching slightly below the level of the rachidian. Both uncini are curved and carry four cusps."

\section{Egg-cluster of Purpura succincta Martyn.}

$$
\text { (Plate xxxiii., figs 31, 32.) }
$$

During an excursion of the Field Naturalists Club, on 30th Sept. 1905, several specimens of Purpura succincta were observed in the act of depositing masses of ova round the trunks of the Ascidian, Cynthia prceputialis, at low tide mark on Wyargine Point, Middle Harbour.

As no account of these has appeared in literature, I give an enlarged view of a single unhatched capsule, and a sketch of a small cluster. Most capsules were a pale cream colour, but some were stained with purple. Each stood erect on a common membrane; the height of each was about $9 \mathrm{~mm}$. and the longest diameter about $6 \mathrm{~mm}$. When tightly packed the summits were rhomboidal, but oblong when separate, flat, surrounded by a rim which is often emarginate on one side. Across the major diameter is a streak and near the centre a clear spot which appears at first sight to be a perforation.

The egg-capsule of an unknown mollusc from Tranquebar, figured by Lund,* has a great resemblance to that now illustrated.

According to the description and figures of C. W. Peach, $\uparrow$ the capsules of Purpura lapillus differ by being stalked and by having a caducous operculum.

The young shell, dentition and operculum have already been figured in these Proceedings. $\ddagger$

* Ann. Sci. Nat. (2), i. Zool. 1834, p.99, pl. vi., f.2.

† Ann. Mag. Nat. Hist. xi. 1843, p.28, pl. i, , A. f.1-3.

$\ddagger$ Vol. xxvi. 1902, p.538, pl. xxix, , f. 1, 6, 8. 


\section{Mitromorpha pallidula, n.sp.}

(Plate xxxii., fig.26).

Shell small, narrow fusiform, blunt at each end. Whorls wound obliquely, five including a protoconch of a whorl and onehalf. Colour dull white; on the last whorl are two narrow, pale brown, spiral bands, one on the periphery, the other between it and the canal; the lower one is more defined and spreads over five ridges and furrows. Sculpture : the dome-shaped protoconch is carved with fine, close, radial riblets, and concludes with a slight varix. Adult sculpture commences suddenly with seven evenly spaced spiral ridges and equal furrows; these gradually increase in size and number. On the last whorl the ridges amount to twenty-six, growing smaller and more crowded anteriorly. The ridges are square in section, polished, and a little narrower than the flat furrows, which are radially striated. Aperture narrow, columella excavate, anal sinus indistinguishable, canal a notch. Length $4 \cdot 6$, breadth $1.5 \mathrm{~mm}$.

Hab.-Manly Beach, near Sydney; a single specimen collected by Miss L. Parkes.

T y p e.-Miss Parkes has generously presented her type specimen to the Australian Museum.

The novelty belongs to a small group comprising $M$. brazieri Smith, from this State, $M$. substriata Suter, and $M$. suteri Murdoch, from New Zealand, which though lacking a columellar fold, has been referred by Smith* to Mitromorpha. This group does not embrace $M$. alba Petterd, wrongly thought by Tate and Mayt to be the same as M. brazieri.

Since writing the above, Mr. W. L. May has shown me a specimen taken by Mr. A. Morton and himself in 24 fathoms off the mouth of the Derwent River, Tasmania.

Pleurotoma sterrha Watson.

Every detail of figure, description and locality given for this species so exactly corresponds to the characters mentioned by

* Proc. Zool. Soc. 1891, p. 486.

† These Proceedings, xxvi. 1891, p.456. 
Smith for his Pleurotoma torresiana* that repeated comparison confirms me in the belief that both names are based on the same shell. If this be so, priority must be awarded to Watson, whose preliminary description $\dagger$ of this Torres Straits shell appeared on November 3rd, 1881.

\section{Conus coxeni Brazier.}

Brazier, Proc. Zool. Soc. 1875, p.34, pl. iv. f.4.

Messrs. G. Gross and C. J. Wild, who have frequently collected the species in and around Moreton Bay, consider that Conus innotabilis Smith $\ddagger$ intergrades with $C$. coxeni. They showed me a series of intermediate forms, in which the spire was more or less elevated and the spiral grooves on the shoulder were more or less developed.

\section{Acteon roseus, n.sp. \\ (Plate xxxiii., fig.42.)}

Shell large, ovate-acuminate, rather thin, spire acute. Whorls seven, round-shouldered, parted by channelled sutures, surface smooth and glossy. Colour a pale flesh-pink, darkest behind the aperture, interrupted by a broad white peripheral band. Sculpture: narrow, shallow punctate grooves numbering about thirty on the last whorl, and on the two previous six each, crowded at the base and wider spaced towards the suture, separate smooth flat-topped narrow spiral riblets. Base perforate excavate around the umbilicus. Aperture half the total length of the shell, rounded below; columella broad with a reflected margin; plication not prominent; inner lip spreading a sheet of callus on the base of the previous whorl. Length 15 , breadth $8 \mathrm{~mm}$.

$H a b$. - I have only seen two specimens, one the type, was gathered by Mr. J. Brazier in the dyke-trough at Wyargine Point, Middle Harbour, Sydney. The other I collected in August, 1900, near Eden, N. S. Wales.

Ty p e.-To be presented to the Australian Museum.

* Zool. Coll. Alert, 1884, p.37, pl. iv., f.D, D1.

† Journ. Linn. Soc. xv., p.426.

† Proc. Zool. Soc., 1891, p.487, pl. xl., f.1. 
Superficially the novelty has a general resemblance to the European $A$, tornatilis Linn. From $A$. austrinus Watson, the only species yet recorded from this coast, it is easily separated by its large size, different colour and sculpture. It is also twice the size of any of the genus described from Australian Tertiary beds.

There is a closely allied species from 110 fathoms off the Great Barrier Island, New Zealand, which my friends Messrs. R. Murdoch and $\mathrm{H}$. Suter are about to describe as A. cratericulatus. The New Zealand shell differs by being much smaller, with sharper sculpture, the grooves being broader and deeper and crossed by more distant and elevated threads.

Tethys norfolkensis Sowerby.

(Plate xxxiii., figs.33, 34).

Aplysia norfolkensis Sowerby, Conch. Icon., xvii., 1869, pl. x., fig. 42 .

This species has not been found, as the name falsely implies, at Norfolk Island. The type was taken by Brazier in Sydney Harbour. As the species has hitherto rested on the shell alone, I take the opportunity of supplying a figure and description of an animal procured during an excursion of the Field Naturalists' Club to Balmoral.

The animal in extension was about $40 \mathrm{~mm}$. long, but, as its shell was smaller than others I have seen, I suppose it to be a small specimen. In colour it was the brown of the kelp weed, spotted with scattered white dots, and edged with black along the margins of the lobes and on the tentacles. Parapodial lobes short, united behind, with digitate margin, free from the siphon. The crown of the shell protruded through an opening in the centre of the mantle. On the hind right side the mantle is produced into a large orifice enclosed by upstanding lobes. From the shell the mantle is rayed with brown and white. The branchiæ in life are entirely concealed. Tail rather long. The animal kept in confinement did not use its lobes for swimming, and emitted purple when annoyed. 
The exposure of the shell and production of mantle in a tube connects this with the European $T$. depilans Linn., and consequently places it in the typical section of Tethys as restricted by Pilsbry.*

The shell does not differ from that of $A$. brunnea Hutton, $†$ nor, if I can trust my recollection of the type, from that of $A$. tryoni Meinertz. Probably these and others will be reduced to the synonymy of $T$. norfolkensis when they are carefully re-examined.

\section{Cassidula zonata $H$. and A. Adams.}

(Plate xxxiii., fig.30.)

No illustration has yet appeared of this species, a deficiency which I now supply. The animal occurs under sticks and stones near high water mark along the edge of mangrove swamps, associated with Ophicardelus, Assiminea, T'atea and Salinator. It was originally described from Sydney. $\ddagger$ A better account was afterwards framed by Pfeiffer. $\S$ It was redescribed by Tenison Woods\| as Auricula (Rhodostonıa) dyeri, from the north coast of Tasmania. This name was recognised as a synonym by W. F. Petterd. T The species was reported from Port Mackay, Queensland, by Schmeltz, ${ }^{*}$ but I have not myself traced it north of Moreton Bay. From the last monograph of the Auriculidæ in the Conchylien Cabinet, the species has been entirely omitted. The example figured is from the Lane Cove, and is $10 \mathrm{~mm}$. in length.

Pinna serrata Sowerby.

The description of this species by G. B. Sowerby $\dagger \dagger$ preceded the figure $+\ddagger$ by a few months. No locality was given in the first

* Man. Conch. xvi. 1895, p 67.

† Trans. N.Z. Inst. vii. 1875, p.279, pl. xxi.

† Proc. Zool. Soc. 1854 (1855), p.32.

$\S$ Cat. Auricul. Brit. Mus. 1857, p. 84.

\| Proc. Roy. Soc Tas. 1875 (1876). p. 158.

IT Proc. Roy. Soc. Tas. 1879, p.70.

** Mus. Godeffroy, Cat. v. 1874, p. 88.

t† Cat. Shells coll. Tankerville, 1825, Suppl. p.v.

$\ddagger \ddagger$ J. de C. Sowerby, Genera rec. foss. Shells, Pt. xxvi. 1825, pl.102. 
account, but Hanley* later ascribed the species to New South Wales, a statement which though accurate at the time, ceased to be so after the political separation of Queensland.

Reeve introduced confusion by describing this shell firstly $\dagger$ as Pinna serra, presumably a new species, from Moreton Bay, and secondly $\ddagger$ as $P$. serrata Solander, from the West Indies. The species is not included in any West Indian catalogue to which I have access.

This mistake dislocated the literary history of the species. Subsequent authors, von Martens, $\S$ Smith, $\|$ and Clessin lost sight of G. B. Sowerby's original name, and have used P. serrata Reeve, for the species.

The shell seems to be a rare one. The locality of Moreton Bay has been recently confirmed by Mr. G. Gross, and I have seen an example from Keppel Bay.

\section{Standella nicobarica Gmelin.}

The first regular binomial given to this species was that of Mactra nicobarica, which Gmelin** founded on an illustration by Chemnitz. $\dagger \dagger$ Several subsequent writers appeared to have confused this Oriental species with the European S. rugosa Gmelin. But Reeve figured Gmelin's M. nicobarica under the title of Mactra cegyptiaca. $\ddagger$ For a clue to this complication I am indebted to a reference by Dr. Dall.s§

The only Australian record of this species is by Angas, |||| who reported it, under the name of Merope cegyptiaca, from Lake Macquarie, N.S.W. I can add that it extends thence northward along the whole Queensland coast.

* Recent Shells, 1843, p.254.

†Conch. Icon. xi. Pinna, 1858, pl. xxiii., f. 43. $\ddagger$ Op. cit. pl.xxxix. f. 65 .

$\S$ Ann. Mag. Nat. Hist. (3), xvii. 1866, p.86.

i) Proc. Zool. Soc. 1891, p. 433.

- Conch. Cab. viii. Pt. i. 1891, p.60, pl.28, f.2.

* Syst. Nat. xiii. 1790, p.3261.

t† Conch. Cab. vi. 1782, pl. xxiv. f.237.

+ Conch. Icon. viii., Mactra, pl. xx., f.112, 1854.

$\S \S$ Trans. Wagner Free Inst. Science, iii. 1898, p. 887.

|||| Proc. Zool. Soc. 1871, p. 100. 
What von Martens figured* under the name of Lutraria (Merope) nicobarica Gmel., appears to be a different species.

Ectorisma granulata Tate.

Tate, Trans. Roy. Soc. S. Australia, xv. 1892, p.127, pl.i., fig.3,3a.

A living specimen of this was taken by Mr. G. H. Halligan and myself 16 miles east of Wollongong in 100 fathoms, and again by Mr. W. F. Petterd and myself 27 miles east of Sydney in 300 fathoms. It had not before occurred beyond the coast of South Australia.

Crassatellites kingicola Lamarck.

In the last part of this series I discussed the nomenclature of this species, and concluded that the name of $C$. ponderosus Gmelin ought to be applied to it. Australian naturalists have since benefited by an examination of the question by Mr. E. A. Smith. $\dagger$ With greater skill in the elucidation of such problems, and with material and literature inaccessible to me, Mr. Smith shows that the southern origin ascribed by its introducer was false, and that Gmelin's C. ponderosus is the Grignon fossil C. tumida Lamarck. This decision permits the use of $C$. kingicola Lamarck for the Australian shell.

Dr. J. C. Verco has recently discussed $\ddagger$ the range and variation of the species in South Australia.

Condylocardia ovata, n.sp.

(Plate xxxi., figs.5, 6.)

Shell rather large for the genus, glossy, thin, translucent, obliquely ovate. Colour white. Sculpture: about fourteen concentric wave ribs, more or less developed, close microscopic concentric threads oblique to the main sculpture. Prodissoconch prominent, no free edge, a gently swelling central imperforate boss, finely concentrically corrugate. Muscular impressions

* Journ. Linn. Soc. Zool. xxi. 1887, p.217, pl. xvi., f.7a, $b$. † Journ. of Malacology xii. 1905, p.26.

‡ Trans. Roy. Soc. S. Austr. xxix. 1905, p.169. 
distinct, edge of valve not plicated, thin. Specimen drawn; height 1.35 , length 1.55 , diameter of single valve $0.45 \mathrm{~mm}$. Another specimen; length 1.85 , height $1.4 \mathrm{~mm}$.

Hab.-Manly Beach, in shell sand (Miss L. Parkes), several specimens.

T y p e.-To be presented to the Australian Museum.

Half of this genus have radial sculpture, half concentric. From the latter the novelty is distinguished by large size and more oval form.

\section{On the genus Cyamiomactra.}

A preliminary account of this genus was given by Felix Bernard* based on material dredged by Filhol off Stewart Island, New Zealand. The petaloid cardinal of the left valve suggested to him a Mactroid relationship, but he acknowledged that the genus could not be regarded as an arrested phase of the Mactroid model. The untimely death of this brilliant writer deprived the world of the full account of the development and affinities of Cyamiomactra on.which he was then engaged.

The next reference to the subject was by Dr. Dall, who grouped $\dagger$ this genus in the Leptonacea.

Bernard's account was rather generic than specific, and it was after much difficulty that I detected the species in Stewart Island material kindly supplied me by Mr. A. Hamilton. To facilitate recognition of it the original account is now supplemented by a drawing of the shell (plate xxxi., figs.7, 8).

Its range in New Zealand has been by Murdoch extended to Whangaroa Harbour in the North Island. $\ddagger$

Laying stress on the entire pallial line, and inviting comparison between the hinge of Cyamiomactra and that of Cuna, I would suggest another relationship for this puzzling genus, and class it in the family Crassatellitidce. It also seems to me that another aberrant genus Hemidonax, which has been referred to many different positions in the taxonomic scale, is a kindred form,

* Bull. Mus. Hist. Nat. 1897, p. 311, fig. 2.

† Trans. Wagn. Inst. iii., 1900, p.1116.

† Trans. N.Z. Inst. xxxvii, , 1904 (1905), p.231. 
and may likewise find an appropriate abiding place in the Crassatellitidce.

Enlarging Cyamiomactra by the addition of two Australian species the genus may be thus reviewed :-

C. problematica, larger, compressed, no ribbing.

C. mactroides, smaller, inflated, ribbed from end to end.

C. communis, smaller, inequilateral, ovate, ribbed medially.

C. mactroides Tate and May* was originally described from Tasmania. Additional drawings of the shell and hinge (plate xxxi., figs. 9, 10) are now tendered in support of the transference from Cyamium to Cyamiomactra. As I recognise it, the species varies so widely that on first acquaintance the extremes appeared worthy of specific differentiation. In shape it is more or less inflated, a very swollen form being expressed by Tate and May's figure. In colour it is white or white tinged at end and apex with brown, or all brown, or entirely bright pink. Specimens from the northern extremity of its range are dwarfed.

The following localities are known to me :-Eagle Hawk Neck, Tasmania (Mrs. C. Hedley), Western Port, Victoria (J. H. Gatliff), Wreck Bay, N.S.W. (self), off Port Kembla, N.S.W., in 63-75 fath. ("Thetis"), ocean beaches around Sydney (Miss L. Parkes), Capricorn Group, Queensland (self).

\section{Cyamiomactra communis, n.sp.}

$$
\text { (Plate xxxi., figs.11, 12, 13.) }
$$

Shell elongate-ovate, shallow, inequilateral, the posterior end produced, the anterior rounded. Colour dorsally dark cinnamonbrown, which gradually fades into translucent ice white, medially a dozen narrow opaque rays, which do not represent a thickening either within or without but are a denser substance contrasting with the translucent ground. They fall short of the umbo. Prodissoconch smooth, oval, rather flat and well defined. Sculp-

* Trans. Roy. Soc. S.A., 1900, p.102; these Proceedings, xxvi., p.433, pl. xxvii., f.103. 
ture: dense, fine, regular concentric threads. On the inner ventral margin are a dozen small tubercles answering to the opaque rays. Length $2 \cdot 1$, height $1 \cdot 5$, depth of single valve $0.25 \mathrm{~mm}$.

Hab.-Manly Beach, near Sydney, type (Miss L. Parkes); Wreck Bay, N.S.W. (self); Port Fairy, Victoria (the late Rev. T. Whan).

Ty pe.-Miss Parkes has generously promised to present the type to the Australian Museum.

Montacuta semiradiata Tate.

(Plate xxxi., figs.1, 2.)

Tate, Trans. Roy. Soc. S. Aust. 1888, p.63. pl. xl., f.2.

This species is externaliy so like what I have just described as Cyamiomactra communis that Prof. Tate distributed C.communis to his friends under the label of $M$. semiradiata. To better elucidate the difference, I have by the kindness of Dr. J. C. Verco been enabled to figure one of the type-lot of $M$. semiradiata.

$M$. semiradiata does not appear to me to be happily placed, but I am not now prepared to decide on a better generic location. Perhaps it is related to Poromya.

Neolepton rostellatum Tate.

$$
\text { (Plate xxxi, figs.3, 4.) }
$$

Kellia rostellata Tate, Trans. Roy. Soc. S. Aust. xi. 1888 (1889), p.63, pl. xi., f.14.

Dr. Verco has kindly lent me the type specimens of this species. From the hinge, now for the first time figured, it seems that the species was not properly classed in Kellia, and I propose to transfer it to Neolepton. The latter genus has not hitherto embraced an Australian example, but two species from New Zealand were assigned to it by Bernard.

The type series of Prof. Tate exhibits considerable variation in colour and contour. A more oblong shell than that originally figured is selected for illustration. 
BoRNIA LEPIDA, n.sp.

(Plate xxxii., figs.22, 23.)

Shell of rather variable outline, oblong, subequilateral, compressed, umbo prominent, ventral margin perceptibly sinuate. Colour uniform pale brown. Sculpture: fine, dense, radiating threads, interrupted by concentric growth lines. Depth of single valve 1 , height 4 , length $6 \cdot 3 \mathrm{~mm}$.

Hab.-Manly Beach (Miss L. Parkes), Watson's Bay (H. L. Kesteven), Maroubra, Balmoral, and Wreck Bay (C. Hedley), and Long Bay (H. S. Mort). Not uncommon in shell sand on the ocean beaches near Sydney.

T y p e.-To be presented to the Australian Museum.

The novelty is very like B. radiata* from 111 fathoms off Cape Byron, but differs by being almost equilateral.

Kellia suborbicularis Montagu.

Mya suborbicularis Montagu, Test. Brit., 1804, pp.39, 564, pl. xxvi., fig. 6 .

Modern writers have developed a world-wide range for this species, but it has so far escaped inclusion in Australian catalogues. Hanley $\dagger$ considered that Amphidesma physoides Lamarck $\ddagger$ described from King George's Sound, W.A., was identical with Montagu's species. He noted later that the type of $A$. physoides, which he had examined in the Paris Museum in 1843, was, according to Recluz, destroyed in 1856.ई

Smith has repeatedly $\|$ expressed his conviction that Erycina rotunda Deshayes 9 from Moreton Bay, Queensland, cannot be separated from $K$. suborbicularis.

* Hedley, Records Austr. Mus. vi. 1905, p.48, f.12.

$\uparrow$ Cat. Recent Shells, 1843, p.43.

‡ Anim. s. Vert. v., 1818, p.493. § Op. cit., 1856, p. 343 .

\| Ann. Mag. Nat. Hist. (6), x., 1892, p.132 and Proc. Malac. Soc. v., 1902, p. 163.

ণ Proc. Zool. Soc., 1855, p. 181. 
Joannisiella Sphericula Deshayes.

(Plate xxxii., figs.18, 19, 20, 21.)

A small bivalve from the Parramatta River was recorded and described by G. F. Angas * under the name of Mysia sphcericula or Diplodonta spharicula Deshayes. He did not as usual quote a reference, and apparently regarded the name as an unpublished one.

Subsequent authors who referred to this species and failed to trace the name to its source are, Tryon, $\dagger$ Tapparone Canefri $\ddagger$ and Pritchard and Gatliff. $\$$ The latter, who extended the range of the shell to Victoria, indeed substituted Angas for Deshayes as the author of the species. Though Deshayes never described a Diplodonta under this title, it is obvious that his Cyrenella sphcericula \| from Moreton Bay, Queensland, was based on the species under discussion.

The thin swollen shell, epidermis and other characters, do not suit the usual classification of this in Diplodonta, but appear to claim for it admittance to a genus Joannisiella, proposed by Dall for an Oriental group, typified by Cyrenoida oblonga Hanley. ${ }^{* *}$

As this species has not yet been illustrated, I add drawings of a specimen from Sydney Harbour, $18 \mathrm{~mm}$. long and 16mm. high.

\section{Philobrya parallelogramma, n. $\mathrm{sp}$. \\ (Plate xxxii., figs. 14, 15, 16.)}

Shell rather large for the genus, solid, considerably inflated, very inequilateral; in outline the younger shells are nearly square, but the older approach a parallelogram. Colour white. Sculpture : seventeen strong radiating ribs which undulate the margin; a concentric system develops cross-bars in the furrows and

* Proc. Zool. Soc., 1867, p. 927.

+ Proc. Acad. Nat. Sci. Philad. 1872, p.95.

$\ddagger$ Acad. R. Sc. Torino (2) xxviii., 1873, p. 238.

§ Proc. Roy. Soc. Vict. (2) xvii., 1904, p.224.

|| Deshayes, Proc. Zool. Soc., 1854 (1855), p.340.

- Nautilus ix., 1895, p.78.

•* Hanley, Recent Shells, 1844, pl. xv., fig 6. 
nodules on the ribs. The rim of the prodissoconch stands out from the summit of the valve; it is semicircular, the edge turned up, the interior tumid, and the centre umbilicate. Length $2 \cdot 45$, height $3 \cdot 25$, depth of single valve $1 \cdot 3 \mathrm{~mm}$.

Hab.-In shell sand on Manly Beach, numerous specimens. (Miss L. Parkes).

T y p e.-To be presented to the Australian Museum.

By its sculpture the present form is well distinguished from other Australian species. But it closely resembles P. costata Bernard, from South New Zealand, which slightly differs by fewer and bolder radial ribs.

While on the subject of Philobrya I may take this opportunity of observing that the genus Limarca of Tate* is synonymous. Prof. Howchin has very kindly permitted me to examine the types preserved in the School of Mines, Adelaide. Mr. J. Dennant also lent me co-types received from the author. From both sets it is apparent that in creating the genus Prof. Tate used two species of different genera, one a Philobrya, the other a Limopsis. But the example labelled "type" is the Philobrya, and to it rather than to the Limopsis is applicable the epithet "angustifrons," and the opening descriptive phrase, "very inequilateral." The Limopsis is an aberrant form, and probably undescribed. Before returning his example to Mr. Dennant, I took the accompanying sketch (Plate xxxii., fig.17) of the Limopsis hinge.

Arca venusta Dunker.

Dunker, Zeitschr. f. Mal. 1852, p.59; id. Novitat. Conch. 1867, p.91, pl. xxxi., f.1.

This bivalve is an addition to the Australian fauna. As separate valves it occurs frequently on the beach at Mapoon, entrance to the Batavia River; and I noticed it again at Karumba, mouth of the Norman River, Gulf of Carpentaria, Queensland. Dr. E. Lamy, of Paris, a specialist on this genus, has kindly confirmed my identification.

* Trans. Roy. Soc. S. Austr. viii. p.135, pl. viii., f.5, $a, b$. 


\section{EXPLANATION OF PLATES XXXI.-XXXIII.}

Plate xxxi.

Figs. 1, 2.-Montacuta semiradiala Tate; hinge and valve.

Figs. 3, 4.-Neolepton rostellatum Tate; hinge and valve.

Figs. 5, 6.-Condylocardia ovata Hedley; hinge and valve.

Figs. 7, 8.-Cyamiomactra problematica Bernard; hinge and valve.

Figs. 9, 10.-Cyamiomactra mactroides Tate and May; hinge and valve.

Figs. 11, 12, 13.-Cyamiomactra communis Hedley; hinge and valve, and exterior and interior.

\section{Plate xxxii.}

Figs. 14, 15, 16.-Philobrya parallelogramma Hedley; young and adult valve, and prodissoconch.

Fig. 17. - Limarca angustifrons Tate (partim); hinge.

Figs. 18, 19, 20, 21.-Joannisiella spharicula Deshayes; hinge and valve; full and profile.

Figs. 22, 23.-Bornia lepida Hedley; valve; full and profile.

Fig. 24.--Rissoa emblematica Hedley.

Fig. 25.-Rissoa pulvillus Hedley.

Fig. 26.-Mitromorpha pallidula Hedley.

Figs. 27, 28, 29.-Assiminea tasmanica Ten. Woods; shell and operculum; exterior and interior.

Plate xxxiii.

Fig. 30.-Cassidula zonata A. Adams.

Figs. 31, 32.-Purpura succincta Martyn; cluster of ova and magnified single capsule.

Figs. 33, 34-Tethys norfolkensis Sowerby; from the side and from above.

Fig. 35. - Diala translucida Hedley.

Fig. 36.-Diala monile A. Adams.

Figs. 37, 38.-Emarginula dilecta A. Adams; full and profile.

Figs. 39, 40.-Eulimella anabathron Hedley; shell and apex (magnified).

Fig. 41.-Odostomia opaca Hedley.

Fig. 42. - Actcoon roseus Hedley.

Fig. 43.-Leiostraca inusta Hedley. 


\section{$2 \mathrm{BHL}$ Biodiversity Heritage Library}

Hedley, Charles. 1906. "Studies on Australian Mollusca. Part IX." Proceedings of the Linnean Society of New South Wales 30, 520-546.

https://doi.org/10.5962/bhl.part.12915.

View This Item Online: https://www.biodiversitylibrary.org/item/30106

DOI: https://doi.org/10.5962/bhl.part.12915

Permalink: https://www.biodiversitylibrary.org/partpdf/12915

\section{Holding Institution}

MBLWHOI Library

\section{Sponsored by}

MBLWHOI Library

\section{Copyright \& Reuse}

Copyright Status: NOT_IN_COPYRIGHT

This document was created from content at the Biodiversity Heritage Library, the world's largest open access digital library for biodiversity literature and archives. Visit BHL at https://www.biodiversitylibrary.org. 